\title{
The Evaluation of Free Education Program at North Kayong District in 2016 Period
}

\author{
Heru Suherda ${ }^{1)}$, Maswardi M Amin ${ }^{2)}$, Fadillah $^{3)}$ \\ ${ }^{1)}$ Universitas Tanjungpura, Pontianak, Indonesia \\ E-mail: root.gg369@gmail.com \\ ${ }^{2)}$ Universitas Tanjungpura, Pontianak, Indonesia \\ E-mail: maswardi.mamin@gmail.com \\ ${ }^{3)}$ Universitas Tanjungpura, Pontianak, Indonesia \\ E-mail: fadilah.fkip@gmail.com
}

\begin{abstract}
North Kayong as a new district for regional autonomy, the elected Bupati formed an assessment team which later identified the Education problems in North Kayong, namely the lack of schools and their distribution in each subdistrict, and the weak support capacity of the community towards education funding, with the limited budget of the Kayong Utara regional government initiating a free education program with the aim of improving access to Education and Quality of Education. Public policy cannot be released as soon as it has been established, policies must be monitored and one form of the monitoring mechanism is policy evaluation. This study aims to conduct, context evaluation to find out the legal basis, background and objectives of the program, evaluation of input to find out the characteristics of the recipient of the program, providers, and sources of financing, process evaluation to find out the time allocation, mechanism for the process of financing and program implementation, and evaluation product to find out the achievements in this free education program. Evaluation is done with the CIPP evaluation model. The results of the study 1) In the context component known, the legal basis of the implementation of the free education program is the Regent Regulation No. 60A in 2009 and the Kayong Utara District Regulation No. 5 of 2014, in the implementation of free education free education program will be achieved, 2) The Imput component is known that the program targets are school-age children who are domiciled in KKU, and the program implementers are the Education Agency that has management fields for elementary to secondary education, for budgeted funding is always exceeding above $20 \%$ of the North Kayong District APBD value with an average of 2010-2016 25.83\% of the APBD value, 3) Budgeting is carried out by a mechanism in accordance with the rules of the Ministry of Home Affairs where there is a budget discussion process involving the executive and legislative, on implementation $\mathrm{n}$ free education programs, there are two types of activities, namely School Operational Assistance to finance school management and investment funds in the education sector, 4) the results achieved in 2016 are the increase in the number of TK / SD / SD from 101 schools to 206 schools, SMP / MTs from 32 Schools become 44 Schools, and High Schools / Vocational Schools / MAs from 9 Schools to 22 Schools. The increase in the APK value in 2016 for elementary school level to $125.4 \%$, junior high school $96.77 \%$, and high school to 74.08\%. The APM value also increased, in 2016 the NER SDN became 99.94\%, the NER junior high school became 72.32\%, and the NER SMA became 48.96. School dropouts were also very low in 2016 to 0.00 at the elementary school level, 0.04 at the junior high school level, and 0.29 at the senior high school level.
\end{abstract}

Keywords: Evaluation; Policy; Education

\section{INTRODUCTION}

Policy is something that the government takes to solve a problem that arises. Public policy is the policies made by the government as policymakers to achieve certain goals in the community wherein the preparation through various stages (Dunn: 1999). Public policy cannot be released. Policies must be 
monitored, and one of the monitoring mechanisms is called "policy evaluation." Evaluation is needed to see the gap between hope and reality. Evaluation not only draws conclusions about how far the problem has been resolved but also contributes to clarification and criticism of the values underlying the policy, helps in the adjustment and reformulation of the problem.

The spirit of regional autonomy has opened up space for the regions to develop their regions and make leaders in the regions carry out innovative efforts to encourage development in their regions, including in the education sector. Development in the field of education is one way to boost human resources that are still very minimal in the area.

Being a new autonomous district and with the smallest PAD in West Kalimantan in 2007, the North Kayong District Government made a bold decision by freeing all tuition fees up to the high school or vocational high school level. From the data presented, more than $39 \%$ of students cannot access education. A large number of students who are of school age but do not get proper education will be a new influence on the future of the nation, especially in the North Kayong district. In 2007 there were $79.04 \%$ of elementary students who did not continue their education to junior high school, at junior high school there were $62 \%$ of students who did not continue their education to the high school level. In 2008 no less sad there were $72.38 \%$ of students who did not continue to junior high school education, from junior high school there were $67.75 \%$ of students who did not continue to high school education.

The appalling condition of education in Kayong Utara is due to various problems, including the lack of schools, poverty, and low motivation in education. With a population of 90,239 in 2007, North Kayong only has 81 elementary schools, six junior high schools, and four high schools. Poverty can be seen from the income per capita of the Kayong Utara population in 2007 which was only Rp 260,000. The low motivation for education can be seen from the low Gross Enrollment Rate (APK) which was only 67 percent in 2007. It happened because most school-age children were absorbed into the fishing business sector.

The free education policy issued starting in July 2009 is expected to be able to increase the Gross Enrollment Rate and the Pure Participation Rate (APM) and fulfill the right to education and realize the compulsory education program up to 12 (twelve) years. Schools that get free education policies start from elementary, middle and high school education on the formal education pathway. With the total budget allocation, the Kayong Utara District government applies free education in its area to students both public and private schools from the primary and secondary education levels. Free education funding in Kayong Utara District is taken from the RAPBD post specifically for all schools.

There are those who are pessimistic that the free education policy can be carried out well because of the large amount of education budget that must be borne by the APBD and the concern of some people about the sense of justice of the community considering that only state schools will enjoy free education policies. During the five years of free school policy, it began to show some changes in the world of North Kayan education. By increasing the APK and APM from the participation of students who continue their education to higher levels of education, even though the numbers shown do not meet the expected numbers. From some of the problems that arise from this free school policy, the author wants to examine more deeply the evaluation of free education policies in North Kayong.

In fact, until now not all education managers in the Ministry of Education and Culture and education managers in the Provincial Education Office and District / City Education Offices understand what is meant by education indicators and what is their relation to accountability, so that in the implementation of educational policies is often not right on target. Quoted from World Education Report (UNESCO, 2016), indicators in education are said to be good if they have five characteristics, namely (1) Relevant to policy; (2) Easy to use; (3) Taken a variable; (4) Technically valid, reliable, and comparable; (5) Easy to measure and use appropriate funds. These five things will be the basis of the author in determining the success of the free education policy indicators in North Kayong Regency, and specifically, the author will refer to Permendikbud No. 23 of 2013 to see the results of the evaluation of this free education policy.

\section{RESEARCH METHOD}

\section{Research Approach}

The research approach used is qualitative research. The qualitative approach in this study is strengthened by descriptive methods.

Types of Research

The type of research conducted in this research is a case or case study approach. In this study, researchers tried to examine more deeply and thoroughly about free education programs in North Kayong Regency.

Research Sites

The location of this study is in the Kayong Utara District Education Office and schools located in Kayong Utara District.

\section{Data Source}

Sources of data in this study use documentary and interviews with the formulator of free education programs and implementers of free education programs. 


\section{Data Collection Procedure}

1. Interview

2. Observation

The object of observation in this study is supporting document documents in the implementation of free education policy, policy implementation steps, factors that become obstacles and supporters in the implementation and how to implement this free education policy.

3. Study Documents

The documents that will be obtained by researchers are those relating to the planning and implementation of free education policy programs in the West Kalimantan provincial KKU.

Data Analysis Type

In this study, the data analysis method used is an interactive analysis model. This interactive analysis model is carried out with three steps of qualitative data analysis, data reduction, data presentation, and verification.

Data Validity Attachment

Departing from this view a more detailed explanation by the researcher to check the validity of the data is as follows:

\section{Credibility Test}

The researcher selected several credibility testing techniques, namely through extension of research time, triangulation, comparing with other research results, and member check. Research data collection starts from May 13, 2018, until July 31, 2018.

Members check or check members involved in gathering information to get reactions in terms of views and situations of data sources or informants, in this case the Regional Secretary KKU, KKU Head of Education and Culture, School Principals, Education Council, Members of KKU Education DPRD, against data that has been organized by researchers, including data accuracy, analytical categories, capturing, and conclusions.

2. Transferability Test

Transferability testing is carried out by researchers by creating reports that describe the reality in detail, clear, systematic and trustworthy. For this on July 22, 2018, the researcher asked an Indonesian teacher named Utin Nurlina, S.Pd as an Indonesian teacher to give opinions as well as input so that the reports made clearer and easier to understand by anyone who read them and arranged according to the correct Indonesian rules.

3. Dependability Test

The data stability test (dependability) is done by asking for opinions, opinions and input to several thesis supervisors, namely Prof. Dr. Maswardi M. Amin, M.Pd and Dr. Fadilah to ensure that the results of the research refer to the consistency of researchers in collecting data, forming, and using concept concepts when making interpretations to draw conclusions. Besides that, he also asked for clarification from Mr. Gunanto, M.Pd, and Mrs. Sri Utami, M.Pd who have experience in developing theses during their Master program.

4. Confirmability Test

Confirmability testing in research is done by member checking or checking members involved in gathering information. The aim is to get a reaction in terms of the views and situation of the data sources or informants, namely from the Regional Secretary $\mathrm{KKU}$, the Head of Education and Culture Office KKU, the Principal, Secretary of the Regional Finance Agency, and Members of the KKU DPRD education commission, to the data that has been organized by researchers, These include data validity, analytical categories, interpretations, and conclusions.

Research Stages

To obtain accurate and clear data in this study, the stages of research conducted by researchers are as follows:

1. Analysis before the field

2. Analysis during the field

3. Analysis after the field

\section{RESULT AND DISCUSSION}

A. Result

The results obtained from the evaluation of free education programs organized by the KKU Government of West Kalimantan Province using the CIPP model, the evaluation results presented include descriptions of context, input, process, and product.

1. Context (Legal Basis)

The components of the context evaluated include the legal foundation of free education programs and the purpose of implementing free education programs at KKU.

a. Legal Foundation

In this aspect the researcher analyzed the documents on the legal basis of the free education carried out by the KKU government, from the results of document analysis, the Free Education providers initially used the legal basis in the form of regent regulations, the KKU Government issued a policy through the Regent Regulations on July 13, 2009, 60. An in 2009 concerning the Provision of Free Education Services at Elementary / MI, Middle / MTS Education Levels, and High Schools / MA / Vocational High Schools at KKU. Then proceed with the issuance of KKU Local Regulation No. 5 of 2014 concerning Free Education.

In addition, the researchers also interviewed several respondents for knowledge about regulations and legislation issued by the local government which provided the foundation for the implementation of free education 
programs at KKU. Among them are respondents who are the organizers or authorized officials and supervisors at the KKU Education and Culture Office, all of whom provide satisfactory answers. Then some middle school principals on the results of the five principals they asked all knew about the legal basis for the implementation of free education programs. It shows that among the implementers of the activity, it has been carried out maximally and comprehensively. The same thing was also acknowledged by the regional secretary of KKU that in the process of formulating and implementing this free education policy the local government involved various aspects of the world of education, be it supervisors, teacher teachers, principals, PGRI, communities and also the education council.

According to the head of the KKU Education Office, the free education program was organized based on the needs and demands of the "mandate of the constitution, it is clear that education is the right of citizens" in accordance with the constitution of article 31 of the 1945 Constitution and then strengthened by the National Education System Law Number 20 of 2003 Article 5 which reads that every citizen has equal rights to obtain quality education.

From the results of interviews with KKU regional secretaries, the problem of education in KKU was of particular concern to the elected regent, Mr. H Hildi Hamid, based on his visit to 43 villages during the $\mathrm{Kku}$ district election campaign he saw that there were still low educational facilities available in each village. Then from the recognition of the KKU regional secretary, the Regent was elected KKU, Mr. H Hildi Hamid then formed an assessment team for accelerating education development at KKU. The regional secretary stated the results of "education assessment until 2008 the number of primary schools in KKU was only 92 units, then junior high schools were only 47 units, and Ma and SMA high schools were only 7 units, this is certainly very inadequate to provide proper education services to all KKU communities are scattered in 5 Subdistricts at that time ". In addition to the lack of educational facilities, the average number of years of schooling in Kayong Utara is only five years, meaning that the students did not arrive until explained by the head of the KKU Education Office.

From the findings, the assessment team analyzed the causes of the low age of learning at KKU, which concluded that there were problems of availability of school access and affordability of education. Furthermore, the head of the KKU Education Office explained "the availability aspect means the extent of the availability of education services. Well, if affordability means also. Is the other available education affordable, for example, it will affect the living burden of the community, for example, the education is not free, of course, there are costs that are a burden they were to enter education at that time ".

Based on data from the KKU statistics center, the number of schools available in KKU is still small. In 2007, there were only 85 schools for primary education, 21 junior high school / MTs, and seven senior high school / MA / vocational high schools. This relatively small amount will depend on limited access for schoolage students. Even in the island district of Maya, there is no high school at all. The total number of students from elementary to middle school level amounted to 16,603 people but when compared to the total population of learning age in 2007 totaled 28,154 people (BPS, 2008). It shows that only $58.97 \%$ of students of learning age who attend school, the lack of schools to provide excess education causes many school-age students who do not attend school or drop out of school, this is one of the bases for the emergence of this free education program, especially the education investment section.

This limited access to education is one of the causes of the still low average school age at KKU. In addition to the problem of lack of access to education, the low economy of the community is also the cause of the lack of education level in the KKU from BPS data in 2008 there were 14,390 people in the poor category. The low level of this economy results in the burden of education that should be borne by society tends to be ignored. According to Article 33 Indonesia Executive Director Santoso, "Students who come from underprivileged families tend to be in low-quality schools, whereas students from families are able to gather in quality schools" (https://goo.gl/r8U6YH accessed on 25 June 2018).

b. Free Education Objectives

From the results of document analysis, the researchers found that the distribution of the program's objectives into two parts, in the first period (2008-2013) the KKU government focused on the direction of the development of free education referring to the $5 \mathrm{~K}$ mission of the Ministry of National Education, namely:

1) K1. Availability of education services (Focus and direction of development in education in Kayong Utara District on expanding access to education)

2) K2. Affordability of education services (The addition of new school units with the concept of applying to pioneer schools continues to be carried out to meet the affordability of education services) 
3) K3. Quality and relevance of education (Improving the quality of educators and educators through practical training and mobile teacher programs)

4) K4. Education equality (Suppresses a very high ratio between male and female students through free education)

5) K5. Certainty of education services

6) (As a concrete step from the vision and mission of the North Kayong regent towards free education with the issuance of the Regulations No. 60.a in 2009)

And in the second period of 2014-2018 free education programs will focus on improving the quality and quality of education. The direction of education development in KKU has been stated in the second mission of the regent of $\mathrm{Kku}$ "Building KKU's HR that is noble, healthy \& intelligent."

2. Input

Input evaluation is related to the input to be processed. At this stage, the input (input) of the planned free education program includes:

Characteristics of North Kayong
Community

According to Republic of Indonesia Law No. 6 of 2007 and Minister of Home Affairs Letter No. 135/439 / SJ On February 27, 2007, the area of the KKU area was 4,568.26 km2. This area is relatively small compared to the districts/cities in West Kalimantan. Geographically, KKU is located on the south side of West Kalimantan Province or in position 043 '5.15 "South Latitude up to 146 ' 35.21" South Latitude and $108 \quad 40 \quad 58.88$ "East Longitude up to 11024 ' 30.50 "East Longitude.

Based on the 2010 population census, the number of residents in KKU in 2010 was 95,594 people $(48,835$ people male and 46,759 female females). Of the five sub-districts at the beginning of the formation of the KKU, it consisted of people with low income. From the results of the assessment carried out by the accelerating development team of North Kayong education, it was known that the KKU community viewed education as still something luxurious because it required a high cost. As a result, the participation of students was still low. BPS data in 2009 showed that groups of children aged 15 years and under-reached $45.29 \%$ of the total population of North Kayong, this data shows the large number of school students in KKU. Characteristics of Program Organizers

The organizer of this free education program is the North Kayak Education Agency, which collaborates with the school where the Education Office as the distributor of education funds and the school is the party implementing the education program. The Office of Education and Culture has every area for each level of education starting from the basic level that supervises elementary and junior high schools; then there is also the field of secondary education which supervises high schools and vocational schools, and most recently is the field of non-formal education and early age education. b. Financing

In this free education program, it certainly requires financing in support of programs to run well. The financing carried out by the KKU government through the budget line in the Education Office is in the form of education operational assistance (BOP) as well as investment financing in education units. In BOP several budget items are financed including building operations, teaching and learning operations, the cost of maintaining school facilities and infrastructure, the cost of organizing evaluation of learning outcomes, and the cost of providing student uniforms. For investment financing in education units in the form of the cost of building roads to school, the cost of building school buildings, the cost of providing laboratory practice equipment and also reading books.

3. Process

Process evaluation related to the management of inputs to achieve the objectives set for the program objectives. In the evaluation process, free education programs include:

a. Budgeting and Allocation Process for Free Education Programs.

b. Mechanism for proposing infrastructure facilities supporting the teaching and learning process.

From the results of the research the data is presented as follows:

a. Free education program budgeting process.

From the results of interviews with the secretary of the KKU Regional Finance Agency, the budgeting process for the education program originated from the KKU Education and Culture Office's proposal, the budgeting process began with the vision and mission set by the KKU regent, in the first period the regent carried the vision "The realization of healthy, intelligent individuals, believing and being devoted, noble, independent and skilled "is then explained in the mission of the KKU Education Office, namely:

1) Organizing the development of basic education in the framework of educational equality and improving the quality of graduates

2) Organizing and developing general secondary education, improving the quality of graduates so that they can compete in entering higher education; 
3) Organizing vocational education, so that they have high skills and are able to compete in entering the job market

4) Optimizing character education in all levels and types of education through relevant subjects

5) Organizing and developing education outside the school in completing blind and providing skills so that they can live well

6) Prepare young people who are innovative, creative and noble and noble-minded

7) Fostering and training sports to increase physical fitness and prepare sports seeds

8) Procurement and Development of educative, administrative and functional personnel to improve service quality

This mission then becomes the basis for the formulation of the RPJND or regional development plan for the regional intermediary which includes the district's vision and mission, priority policy, and program directions. For KKU education is one of the priorities contained in the RPJND then continued with RKPD activities where this process will capture community proposals that are carried out in development planning deliberations starting from the village, sub-district and district levels, concluded by the BKD secretary. The work of the Education Office, the community's proposal, and the thoughts of the DPRD which will later be included in the local government work plan (RKPD) document ". It is in line with the provisions in Permendagri No. 54 of 2010.

RKPD is the basis for the preparation of APBD general policy (KUA) and the establishment of a provisional budget ceiling (PPAS) after PPAS is issued; the SKPD obtains an indicative ceiling (budget amount) while related to the amount of the budget an SKPD to be implemented the following year. The SKPD prepares a budget work plan (RKA) which will then be discussed together with the local government budget team consisting of the Regional Planning Board, the regional financial management and regional asset (DPKAD) services, as well as the economic part of the regional secretariat development (EKBANG). These three SKPD will carry out assistance related to the suitability between regional priorities which are contained in the regent's vision and mission and the RKA that has been prepared by the SKPD. After the RKA has been approved by the local government budget team (TAPD), the RKA is the basis for preparing the regional budget and expenditure plan (RAPD) which will then be discussed again by the legislature (DPRD) together with the TAPD and the Education Office. If it has been agreed then the RAPD will only be ratified into regional income and expenditure (APBD) but the process is not completed until here according to the BKD secretary's statement "The APBD that has been set will be re-submitted to the West Kalimantan provincial government for evaluation related to suitability between priorities the province of West Kalimantan in the field of education with an activity program prepared by the Education Office ".

The same thing was conveyed by the head of the KKU Education Office that "in the education development policy in Kayong must be synchronized with the provincial government policies and the policies of the central government." If the evaluation results from the West Kalimantan provincial government state that there are things that are not in accordance with the provincial priorities, the local government of KKU is obliged to make improvements to the APBD. After repairs based on the recommendations of the provincial government, a budget implementation document (DPA) was issued which became the basis for the implementation of the Education Agency's activity program in the following year; the DPA must have been published in January of the current year.

According to the head of the Education and Culture Office of the KKU for the Education Agency, this free education program is a priority in the preparation of the budget. He said, "for example, we determined the Education Agency $50 \mathrm{M}$ from the fund. We prioritize the expenditure that is obligatory. Mandatory needs approach. BOP is a priority because the BOP is mandatory shopping and it is a strategic policy of the local government ".

Then further explained by the secretary of the Regional Finance Agency, the SKPD also has the opportunity to make budget changes in the third quarter if the SKPD considers it necessary to make changes in the composition of budgeting. For BOP funds, the Head of the Education Office explained that the distribution was divided into 4 quarters where usually in the first month of the first quarter funds had been distributed to school schools through the transfer process from SKPD accounts to their respective school accounts, the direct transfer to the school account was aimed at minimizing the occurrence budget leakage or illegal levies from budget managers. For investment funds in the education sector, the Education Office is responsible for managing and determining which schools get development priorities.

b. Fund allocation for free education programs The results of the interviews and document studies were obtained that for the allocation of funds this educational program was 
fully determined by the regional government concerning the value of $20 \%$ of the total APBD according to the mandate of the constitution. In 2011, the highest number of education funds ever issued by the KKU government, this reflected the motto of the North Kayak regent, Mr. H. Hildi Hamid, namely "All-out for education." However, after the researcher traced the budget further, it turns out that the education function fund is not only found in the Education Office, according to the statement from the head of the Regional Finance Agency's budget section, KKU stated "not all education budgets are in the Education Office, for example, UKS education funding in the department health, or in the library service or the social service for scholarship program funds.

Budgeting for education function funds is always above $20 \%$ exceeding the mandate of the law; this shows the commitment of the KKU government in implementing free education programs. Middle-level education is the level that gets the most budget; then these funds will be distributed to each school based on the level of education.

c. Mechanism for proposing supporting facilities and infrastructure

Facilities and infrastructure were still a major problem when KKU was first formed. The lack of availability of school facilities and infrastructure is one of the findings of the assessment team, this is one of the bases for the emergence of free education policies, free education programs also include investment in education funds where the education funds are allocated for the addition of new school units and the addition of new classrooms, supporting laboratories and libraries. Musrembang activities also become the basis for data collection which areas need the construction of facilities and infrastructure. The school was also given the freedom to submit proposals for procurement of facilities and infrastructure, "then the Education Office will conduct data validation through a dapodik program" explained the head of the KKU Education Office.

4. Products

Product evaluation (results) is an evaluation that measures, interpreting the success of achieving the objectives of implementing free education programs. The direction of this free education program is broadly divided into two periods, the first period from 2008-2013 and 2013-2018. In the first period of the local government KKU focused more on increasing the availability of facilities and infrastructure, this was also acknowledged by the head of the Education Office stating "don't speak quality before the participation rate goes up." From the document study conducted by the researcher, the following results are obtained;

a. Number of Schools and Classrooms

In each year the number of study groups and the number of schools in KKU continue to experience this increase shows the seriousness of the regional government in implementing education investment financing. The number of classes that continues to grow will result in more availability of education services. With the addition of school fees, this will be a good trigger in increasing the amount of student learning.

School distribution that is almost evenly distributed in each sub-district shows the availability of adequate education, for remote areas in KKU schools, are also available for secondary education. Archipelagic regions also have access to secondary education.

b. Number of students

The number of students that continues to grow from year to year shows a positive effect of the implementation of free education, regarding providing access to education is increasing and also the elimination of school fees for students so that more help students to finance education.

c. Number of educators

In addition to the availability of facilities and preaching of educators, it is also an important factor in efforts to improve the quality of education. The number of teachers from year to year continues to increase, both elementary, junior high and high school teachers. According to the head of the Education and Culture Office of KKU ". The provision of teachers was slightly hampered when the central government conducted a CPNS moratorium ". The increase in the number of teaching staff was hampered when the central government conducted a moratorium on the receipt of CPNS, starting in 2011, 2012, and continued in 2015, 2016. The KKU government covered the shortage of teachers by recruiting non-permanent employees in the regions and providing flexibility for schools to recruit honorariums. School if school BOP funds are adequate.

A large number of teachers must be in line with the quality of the teacher itself because a large quantity will not be beneficial if it is not accompanied by the quality of the teacher, one indicator of the quality of teachers is the suitability between educational background and the subjects that are empowered.

Quality in the context of educational outcomes refers to the results or achievements achieved by the school at any given period, the results achieved can be in the form of academic 
ability tests such as general test scores or national examinations (Umedaedi: 1994).

d. Indicator of Education Based on mission 2 and mission 3

Mission 2 can be broken down into three, namely broad access, equitable access, and equitable access. To determine whether the extensive mission two access has been implemented properly, six types of educational indicators are used, namely;

1) Ratio of students per class (R-S / K)

2) Class ratio per classroom (R-K/RK)

3) Percentage of library (\% of Library)

4) Percentage of school health business space (UKS) (\% UKS)

5) Percentage of sports venues (\% TOR)

6) Percentage of laboratories (\% Lab)

To find out whether access to education has expanded, the indicator is converted to produce the same units as access values. Extensive access value is the sum of the six access indicators that extend divided by six with the assumption that each broad access indicator has the same role.

To determine whether mission two equitable access has been implemented properly, four types of education indicators are used, namely:

1) Gross enrollment rate (APK) or pure participation rate (APM).

2) Elementary input (AMK) elementary school numbers or AM and special continuing numbers (AM).

3) School service level (TPS) for elementary, middle and high school.

4) Cost unit (SB) for elementary, middle and high school.

To find out the equitable access, the four indicators are converted to produce the same units into equal access values. The value of the four equitable access indicators is then summed and divided by four assuming that each indicator has the same role.

To determine whether mission two access that is fair has been implemented properly, three types of education indicators are used, namely:

1) Gender Differences APK (PG APK)

2) Gender Parity Index APK (IPG APK)

3) Percentage of private students (\% S-SWT).

Mission 3 can be broken down into three categories, namely student quality, teacher quality, and quality of infrastructure. To determine whether mission three is seen from the quality of students has been implemented properly, then used six types of educational indicators, namely:
1) Percentage of New Students Elementary School from PAUD (\% SB PAUD) (SD only)

2) Repeat number (AU)

3) Dropout Rate (APS)

4) Survival rate for Elementary School 5 (AB5 $\mathrm{SD})$ or survival rate $(\mathrm{AB})$ (especially for junior and senior high school).

5) Number of graduates (AL)

6) Average length of study (RLB)

To determine whether the mission three quality of teachers has been implemented properly, three types of education indicators are used, namely:

1) Percentage of teachers eligible (\% GL)

2) Percentage of teacher certificates (\% GS)

3) Student ratio per teacher $(\mathrm{R}-\mathrm{S} / \mathrm{G})$

To determine whether the mission 3 of infrastructure quality has been implemented properly, four types of education indicators are used, namely:

1) Percentage of good classrooms (\% RKb)

2) Percentage of good library (\% of Library)

3) Percentage of good UKS space (\% RUKSb)

4) Percentage of good laboratories (\% Labb) specifically for SMP and SMA

\section{B. Discussion}

In a program, policy program evaluation has a very important role because evaluation will show the extent to which the effectiveness of the program or policy has been implemented. Every program is always followed by evaluation activities, both regarding the results and the processes carried out (Tulung: 2014).

This research will focus on Evaluation of Free education programs at KKU until 2016. The purpose of this evaluation is to determine the effectiveness of implementing free education programs in improving access and quality of education; it is hoped that the findings in this evaluation can be used to improve the quality of free education programs in the future which will come.

Based on the results of the research that was presented by the free education program at KKU, it was considered to have had a significant influence on the development of education in KKU. Furthermore, more fully there are some findings that will be as follows:

1. Context Components

In the context of the free education policy component, it will discuss the background of the emergence of free policies and the legal basis of this free education program, as well as the purpose of implementing the program. From the results of the interview with the regional secretary $\mathrm{KKU}$, it was known that in its implementation there had been prior socialization of this free education program. This socialization was carried out at the beginning of the free education program period, then in each new 
fiscal year the Education Agency issued technical instructions on the implementation of free education programs, especially in the operational education assistance (BOP) section, but there was no further socialization of free education programs. In the field of investment in education units. From the results of interviews with principals, almost all principals only focused on BOP info; the school still did not know clearly about the investment in education that was issued by the Education Office.

About the legal basis it is known that there are two legal foundations used by the KKU regional government to implement free education programs, namely:

a. Regent Regulation Number 60.An of 2009 concerning Provision of Free Education Services at Primary / MI, Middle / MTS, MA / MA / Vocational Education Levels at KKU.

b. KKU Local Regulation Number 5 of 2014 concerning Free Education

This free education program conducted by the KKU regional government has formal relations with national level policies, so the researchers conclude that this is a form of compliance or implementation of Law No. 20 of 2003 concerning the system of national education article 11 paragraph (2) which states that the Government and Regional Government must guarantee the availability of funds for the implementation of education for every citizen aged seven to fifteen years. Even further this free education policy is more advanced than the national education policy because the local government of KKU does not only target elementary and junior high school education up to the level of secondary education both public and private schools.

The KKU regional government has exempted tuition fees to high school or has implemented a 12-year compulsory education, above the national target of 9 years of compulsory education as stated in Minister of National Education Regulation No. 23 of 2006 concerning Content Standards for Primary and Secondary Education Units which still provide cost exemption targets. Education to junior high school, as can be seen in the attachment section, which states that: "National education must be able to ensure equal education opportunities, improve quality and relevance and efficiency of education management. Equitable education opportunities are realized in the 9-year compulsory education program. "

Even though it is in front of national policy, however, the free education policy carried out by the local government of KKU still remains within the corridors of the existing national education policy, namely in article 50 paragraph (5) of Law No. 20 of 2003 concerning National Education System which states that "District / City Government manages primary and secondary education as well as education units based on local excellence," and Law No. 32 of 2004 concerning regional governance which in Article 10 paragraph (3) states that "education affairs is the authority of the Regional Government (autonomous region) because, not included in the group of functions that are the authority of the central government, namely (a) foreign policy; (b) defense; (c) faith; (d) yustisi; (e) national monetary and fiscal; and (f) religion.

From the free education program issued by the KKU regional government, it was seen that the KKU chose the pattern of "welfare state," namely the state that embraces the social needs of the people, especially education, rather than surrendering to the market or private mechanism (Nugroho; 2008). This policy is one soul with Article 31 of the 1945 Constitution concerning education and culture which states that "Every citizen is obliged to attend basic education and the government is obliged to finance it." State responsibility is represented as the responsibility of the KKU regional government in ensuring that every Indonesian citizen those in KKU are entitled to basic education, are required to attend primary and secondary education funded by the KKU regional government.

In the formulation of the legal foundation for this free education program, the executive involves the school and related parties in the process of discussing the legal basis. As acknowledged by the head of Simpang downstream SMA Negeri 1 in the interview results he said that "the Education Office invited several school principals to dissect the socialization of the Bupati's regulation on free education meaning to evaluate those articles certain verses that you might be revised or maybe something is not good." In addition, from the results of interviews with members of the education committee DPRD, it was known that at the time of drafting the regional regulation, discussions were held with related parties. Mr. Rawi, as a member of the education commission, said: "the regional deliberations were conducted with the executives, principals, education councils and related parties." In addition, the council also conducts comparative studies in other regions that already have similar legal products.

From the searches that have been described, it can be concluded that the process of formulating regent regulations and the regional regulations that underlie this free education program is planned and discussed in a structured manner by involving the executive, legislative, and parties with interest in the world of education. At this stage, the local government has carried out the stage of formulating policies and formulation.

Regarding the background that underlies this program, researchers have previously presented it in the research results section. From the results of the study, it was shown that this free education program 
did not appear suddenly and appeared to answer the problems that emerged when the KKU had just formed, an assessment team formed by the KKU Regent identified the problems that emerged in the world of KKU education, from the results of the assessment that became the basis for the preparation of this free education program. This procedure is in accordance with the stages of a public policy that is formed through the stages of "agenda setting, policy formulation, policy adoption/legitimacy, policy implementation, policy evaluation. These stages are carried out so that the policies made can achieve the expected goals (Budi Winarno, 2007: 32-34)".

The assessment team acted as the agenda maker where they identified the urgency of the problem that had to be resolved in KKU in the initial year, Winarno added that "In this process, the government has room to interpret what is called a public problem and priorities on the public agenda are contested. Policy issues (policy issues) are often referred to as policy problems. The formulation of the policy agenda must be based on the level of urgency and essence of the policy.

The process of policy/legitimacy is carried out by the executive and legislature by involving schools, supervisors and the education council. Whereas for the implementation and evaluation process carried out by the Office of Education and Culture.

From the explanation that the researcher has conveyed, it can be concluded that the process of formulating the policy of free education program is a combination of the process of formulating the policy of elite, rational and public choice models. It is said to use an elite model because the public is not directly involved in policy formulation, the local government in this case the regent and the assessment team that has been formed formulate the beginning of this policy as stated in the work vision of the regent. The rational model is said, because the basic principle used is the principle of efficiency to achieve maximum results, with the limitations of ABPD the KKU local government will certainly do the best efficiency so that this free education program is achieved. The public choice model shows that even though the government is dominant in policy formulation, it turns out that in this education policy refers to the choices desired by the community.

2. Input Components

In the input component, input evaluation is related to the input to be processed. At this stage, input into the free education program that has been planned includes the characteristics of the North Kayong Community, the Characteristics of Program Operators and Financing.

In 2009 the North Kayong community was recorded with a population of 98,848 people. For age 5-19 years there are 31,102 or $31.46 \%$ of the total population. Students of this learning age will be the target of recipients of free education programs. From the headmaster's narrative, every student who is accepted at the school in KKU will get this free education program. In the process of admission, new students are always based on the family card of students, so admission will focus on accepting students who are domiciled in KKU, in the new technical admission instructions the school is permitted to accept students from outside the region with a percentage of $5 \%$ of capacity. So it was concluded that every student who has been accepted at a school in KKU would get this free education program.

The North Kayong community, the majority of whom still have low income, are greatly helped by the existence of this free education program, this is also acknowledged by the Chairperson of the Constitutional Court, who stated: "the KKU community is happy with free education." The same thing was also conveyed by other school principals who interviewed, they all stated that the community was very pleased with the free education carried out by KKU's government, this was evident from the absence of a written or written speech.

The local government of KKU has carried out the mandate of the Constitution no. 31 Paragraph 1: Every citizen has the right to education. By providing equitable access to education for all residents in KKU.

Furthermore, the KKU Education Office as the organizer of free education programs has also been considered to have sufficient human resources for program implementation, this can be seen from the organizational structure of the KKU education where there has been a special division of fields for each level of education, namely basic education that supervises elementary and junior high schools and Secondary education level which supervises high schools and vocational schools. Each field has its section for more specific division of tasks, for basic education, there is a section of early childhood education and basic as well as the first level of secondary education section, in the field of secondary education there is a section of vocational and high school sections. This specific division of tasks will optimize service to the school as the spearhead of the free education program. In full the organizational structure of the KKU Education Office will be attached to the attachment sheet.

An important factor in implementing free education programs is budget availability. With a limited budget, the KKU Education Office carries out a strategy of efficient use of the budget. It aims to overcome limitations in the budget. This principle is known as the basic principle in management when there are limitations regarding resources (Nugroho: 2008). Drucker in Nugroho said that the definition of efficiency is "the extent that the results are produced at east cost." This efficiency is carried out by 
specifying specifically the expenditure financed by the regional government in the free education program contained in the technical guidelines for the use of operational assistance funds. Education that is issued annually by the Education Office.

In particular, there are several items that have been set by the Education Agency for funding standards:

a. Personnel costs consist of the costs used for:

1) Payment of honorarium/salaries of nonpermanent teachers and temporary employees who are recruited by the principal at the approval of the Head of the KKU Education Office.

2) Payment of school management honorarium applies to SD / MI, SMP / MTs, SLB, SMA / MA and SMK except the vice principal and coordinator are only for SMP / MTs and SMA / MA, SMK. In determining the deputy head of SMP / MTs, the appointment is adjusted to the number of study groups.

3) KKU Education Office in the context of meetings/coordination, reporting, carried out by the Principal / School Treasurer provided that it refers to the Decree of the North Kayong Regent Number 621 / DPPKAD-D / XII / 2015 concerning the Standard of Official Travel Cost Units for Regents / Deputies Regent, Leader and Members of DPRD, Civil Servants and Employees Not Permanent of 2016 Budget Year, or in accordance with the ability of funds available to foreign education units

4) Assistance to poor students in the form of stationery (notebooks, pencils, pens, rulers) that are selective, and equipped with a certificate of poverty and the student concerned does not get a special scholarship for the poor (BKMM).

5) Assistance in procuring school uniforms for new students;

6) Assistance in procuring sports uniforms for new students;

7) Assistance in procuring school uniforms for all new students.

8) Assistance in the procurement of subject books is used as a handbook for students and teachers (preferably BSE books) which become school inventory books that are lent to students for one semester;

b. Non-Personnel Costs, consisting of costs incurred to finance the procurement of goods and services for needs:

1) The operational costs of the building and educational facilities consist of:

2) Operational Implementation of the teaching and learning process and administration;

With the specific funding item assigned by the Education Office, there will be no errors in the allocation of BOP funds by the school. Regarding financing by the KKU Education Agency, education authorities prioritize this free education program, this is known from the results of interviews with the head of the Education Office. It shows the importance of free education programs for the KKU government.

\section{Process Components}

From the explanation of the results of the evaluation of the process components, it is known that the budgeting process of the free education program involves various parties, both executive and legislative, the executive jointly will carry out planning and assistance to the budget plan, in this case, the Education Office and the regional government budget team work together in drafting the budget, after making a legislative budget formulation also involved in the discussion before the budget is approved, this long and structured process allows the program implementation process to be programmed and directed so that the expected results are realized effectively and efficiently.

In the presentation of the secretary of the regional financial service, it was clear that each component in the government was involved in planning until the budget implementation, the community from the village level to the sub-district level was involved in the budget preparation process through musrembang activities. From the recognition of the Head of the Education Office of $\mathrm{Kku}$, it was also seen that the schools were given the opportunity to make proposals for the addition of facilities and infrastructure, only to be recognized by the Education Office for the realization of the proposal requiring a long time. The Education Office must determine development priorities and data verification of facilities and infrastructure that the school proposes both directly in the field and through the application of basic education data.

In this process evaluation, the local government of KKU has made optimal efforts in the preparation and utilization of resources in pursuing the implementation of effective and efficient free education programs. There is no visible indication of the authoritarian action of the Education Office as the power of budget users to design the education budget. All planned education budgets must support the vision and mission set by the KKU regent even in accordance with the vision and mission of the education program in the province.

In the case of participants participating in the free education program, the education office also does not discriminate against students from outside the North Kayong area, as long as these students are enrolled in schools in the North Kayong region, all are entitled to free education programs provided by the local government North Kayong.

When viewed from the total budget issued by the regional government KKU for the function of education is always above $20 \%$, this has exceeded the law which in the 1945 Constitution article 31 
paragraph 4 states: The State prioritizes the education budget of at least $20 \%$ of the income budget and state expenditures as well as from regional revenue and expenditure budgets to meet the needs for national education. The budget that is input and will be processed in a free education program has exceeded the standards set by the constitution, in 2011 became the year with the highest education function budget percentage of $29 \%$ of the total North Kayong APBD, this shows the government's concern in terms of financing free education program.

In the process evaluation, it was also seen that the program programs carried out to achieve the goals of free education included:

a. The addition of new school units with the concept of applying to pioneer schools continues to be carried out to fulfill the affordability of education services.

b. Improving the quality of educators and educators through the training of prospective principals as well as the program to improve the competence of SD D2 teachers to become S1 in collaboration with FKIP Untan.

c. Suppressing a very high ratio between male and female students through free education.

d. Issued Regent Regulation No. 60.An of 2009 and Regional Regulation No. 5 of 2014 as a legal basis for the implementation of free education programs.

The addition of new school units in the form of pioneering schools will open up access to education for people who live in remote areas, for example, this program is the opening of high schools in the durian area, Matan, and Maya island which are areas with $3 \mathrm{~T}$ criteria, namely lagging, leading and outermost. This pilot school has a composition of 3 classrooms, one library, one laboratory, one teacher room, 1 TU room, and one principal's office. By providing adequate facilities and infrastructure to carry out educational services, the KKU local government has succeeded in creating access to education in the $3 \mathrm{~T}$ area.

The Education and Training Program for prospective principals and the program to improve the competence of elementary school teachers from D2 to $\mathrm{S} 1$ is a manifestation of efforts to improve the quality of education personnel and school management staff so that the quality of education in KKU will increase.

Researchers found that KKU tended to focus on output rather than artisan input focusing on how to achieve educational development goals formulated in free education programs. This practitioner is in accordance with the thoughts of Christopher Pollit, Johnson Birchall and Keith Putman in Nugroho who stated: "decentralization as an economic effort, namely minimizing the costs of existing resources and improving results or performance." KKU regional governments focus more on increasing APK and APM as a result of the free education program. In the context of public administration, the KKU regional government approach can be grouped into the flow of New Public Management (NPM), which in principle moves the focus from the administration of public administration from the process to results (Nugroho: 2008). In NPM, budgetary difficulties are not overcome by the expansion of budget, but by the efficiency of education management by making specific financing items so that their use is right on target.

4. Product Components

Product evaluation will answer the level of success in achieving the goals of free education programs. The free education objectives that will be achieved by the KKU regional government are:

a. K1. Availability of education services

b. K2. Affordability of education services

c. K3. Quality and relevance of education

d. K4. Education equality

e. K5. Certainty of education services

Broadly speaking, if it is connected with the educational mission that has been determined by the Ministry of Education in the preparation of the profile of primary and secondary education in $2015 / 2016$ the achievement of the free education goal is divided into:

a. Realizing Widespread, Equitable, and Fair Access

To determine the purpose of widespread access has been achieved, it can be used to educate indicator data, namely:

1) Ratio of students per class (R-S / K)

2) Class ratio per classroom (R-K/RK)

3) Percentage of library (\% of Library)

4) Percentage of UKS space (\% UKS)

5) Percentage of sports venues (\% TOR)

6) Percentage of laboratories (\% Lab)

From the data that has been described in table 4.10, the education access indicator extends in $\mathrm{KKU}$ in 2016 in the ratio of class students to elementary level 1:19, SMP 1:24, SM 1:27. This ratio is used to see the density of a class based on Basic Education Minimum Service Standards in the Minister of Education and Culture Regulation No. 23, 2013. (Ministry of Education and Culture, 2013). Each class should be in school development planning filled with 32 students for elementary school and 36 students for junior high school. If it is filled in less than 32 for elementary school and less than 36 for junior high and high school then it produces good grades, this shows the ratio of students in KKU is in good grades because it is far from the minimum standards set by the government.

Class ratio data per R-K / RK classroom is used to see whether the use or use of classrooms is suitable for the purpose that each classroom is only used once in teaching and learning activities. If the value is less than 1 means there is a classroom that is 
still not used, while a value of more than 1 means there is a classroom that is used more than once in teaching and learning activities. Ideally is 1 , from table data 4.10 shows the value of $\mathrm{RK} / \mathrm{RK}$ is close to 1 only at the level of secondary education which is worth 1.63. This shows that there is still a shortage of classrooms in secondary education, secondary education is still found the use of library or laboratory space as classrooms. . Whereas at the elementary and junior high school levels have shown an almost ideal value.

$\%$ Perpus is used as a measure to see the availability of libraries in schools because each school should have a library, for library infrastructure at every level it is close to ideal where on average for the primary and secondary level $84 \%$ of schools have libraries. \% UKS is used as a measure to see the availability of health business space in schools because every school should have a UKS room. At the elementary level there is only $19.13 \%$ UKS means there are only 23 schools out of 117 elementary schools that have UKS rooms so that they are far from ideal.

$\%$ TOR is used as a measure to see the availability of sports venues in schools because every school should have a gym, providing a gym for each school is still at a very low level because all schools in KKU still do not have special sports venues, school schools only have sports fields in the form of a volleyball court. \% Lab is used as a measure to see the availability of laboratories in schools because every school should have a laboratory, especially high schools should have 6 types of laboratories and vocational schools have 3 types of laboratories, at the primary level in KKU do not have a laboratory, in junior high school there are only $32.56 \%$ of schools which has a laboratory and this is certainly still far from ideal, at the level of SM there are only $26.81 \%$ of schools that have this laboratory also means it is still far from ideal. \% Perpus, $\%$ RUKS, $\%$ TOR, and $\%$ Lab are ideally $100 \%$. So it can be concluded that the KKU still needs to invest in education by building a UKS room, a Laboratory and a Sports Venue.

For equitable access, it will be seen the elementary school APK data, that is to see the participation of elementary school students in the population aged 7-12 years, APK junior high school level is to see the participation of junior high school students towards the population aged 13-15 years, while the APK level of SM is to see SM student participation in the population aged 16-18 years. In contrast, the primary level NER APM is the participation of elementary school students that is appropriate to the official primary school age; the junior secondary level NER is the participation of junior high school students in accordance with the official age of junior high school.
The data in table 4.11 shows that in 2016 the KKU APK values at the elementary level were 125.54 SMP 96.77 and SM 74.08 high APK values showed high levels of school participation, without regard to the accuracy of school age at the level of education. If the APK value is close to or more than 100 percent, it indicates that there are residents whose schools are not sufficiently old and who are more than they should be. It can also indicate that the region is able to accommodate school-age residents more than the real target. At elementary school level, it has shown the ability of schools in North Kayong to be able to accommodate the school-age population more than the real target. High school level is still not close to $100 \%$. It shows that there are still school-age students who do not attend school or drop out of school. However, if seen from its development from 2008 to 2016 the SM APK has increased by $50.56 \%$, and this is a significant increase with an average rate of $6.32 \%$ per year.

When viewed from 2008 there has been a significant increase in the value of this APK; it can be seen in full from the following graph data:

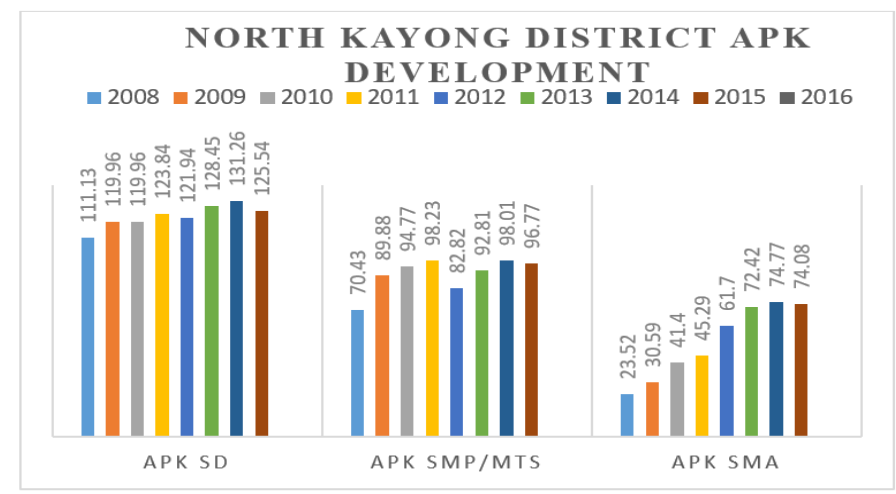

Fig. 1 North Kayong District APK Development (Source of KKU Education and Culture Office) APM measures the absorptive capacity of the education system towards the school-age population, APM shows how much the school-age population has been able to utilize educational facilities according to their level of education. If $\mathrm{APM}=100$, it means that all school-age children can attend school on time (BPS 2016). The NER score for elementary school is close to $100 \%$, which is $99.94 \%$ for the $72.32 \%$ junior high school level and $48.94 \%$ for the new school. The APM value of SM which is still quite low does not mean that free education programs have failed, but if seen from 2008 there has been a gradual increase in APM in each year. Education is one of the long-term investments, so the success of development in the education sector has a positive impact only in the next few years.

This increase in the APK and APM scores shows the success of free education programs in terms of providing equitable access to education. The NER at the secondary school level expanded 
considerably from 2008 to only $17.31 \%$ to $48.96 \%$ in 2016.

The selection of SDK SD is the first access to primary school, while AM is specifically for junior and senior high school because it is continued access to higher education. That is, to enter elementary school do not have to graduate from PAUD but can be directly from households or residents aged 6-7 years. The ideal is $50 \%$. Conversely, if students have not graduated from elementary / MI or Package A cannot continue to junior high school level, so also if students who have not graduated from SMP / MTs or Package B cannot continue to the level of SM / MA. The ideal is $100 \%$. The level of SDK or pure input number is at a value of $69.55 \%$ exceeding the ideal value set. While at the junior high school level it is also close to the ideal value of 89.63 and at the level of SM has reached an ideal value of $100.12 \%$. It shows the equitable access to education available at KKU until 2016.

TPS is used as a tool to assess the level of school education services. If the value is small, it can accommodate students more than the large value. Thus, large access can be interpreted evenly. There is no ideal value yet, so national numbers are used, the relative TPS value of elementary school students is quite small, while at the junior and senior high school level it is large enough so that the level of education services for junior and senior high school can be interpreted evenly.

The cost unit is used as a tool to assess equitable access regarding costs. If the value is small, the participation of the government in education is small, so that the access of schools by the community is uneven. Conversely, if the value is large, government participation in education is very large, so access to schools by the community is easier. There is no ideal value yet, so a policy of $80 \%$ of school operational assistance (BOS) was used in 2015. From the elementary, junior and senior high school levels it has shown great value, the local government of KKU has made very large educational financing participation with an average of 1,900. 885 is far above the value of school operational assistance in 2015, for financing in 2015 each student at the elementary level was funded by 800,000 per junior high school student 1,000,000 and SMA 1,200,000 (Juknis BOS 2015).

The equality of education services where PG APK is used as a measure to assess whether there are differences in education services between men and women. If the value is minus (-) or positive (+) means there is still PG APK in education services. There is no PG APK in education services if the value is 0 . From the data obtained it is known that the PG APK value is still in the minus position indicating there are still differences in educational services. Ideally, the PG APK value must be 0 .
IPG APK is used as a measure to assess whether there is equality in obtaining education services between men and women. If the value is less than $1(0 \ldots)$ or more than $1(1, .$.$) means there is no$ gender equality in education services. Equivalent in education services if the value is 1 . Based on the data obtained, the IPG APK value is close to 1 all, so it can be concluded that ideal conditions are almost fulfilled.

$\% \mathrm{~S}-\mathrm{Swt}$ is used as a measure of justice seen from the status of the school between the state and the private sector as community participation. That is, there is no difference in going to school in public or private. \% S-Swt is not yet known what the ideal value is. However, the higher the value means, the higher private participation in education, from table 5.12 , it can be concluded that there is still a low level of private participation in education given the free education program so that public schools are more of a priority for students in sending these students.

For quality indicators of KKU students seen from input to school, it can be seen from $\%$ SB PAUD specifically for elementary schools. The quality of the student process can be seen from the AU, APS, and AB5 / AB. The quality of student output from the teaching and learning process can be seen from the AL and RLB.

The quality of student input to school is seen from the indicator\% SB PAUD / TK, meaning that the greater the value means, the better because more and more new students entering elementary school come from PAUD graduates. The ideal is $100 \%$. \% Of TK TK only reached $68.08 \%$, this means that in 2016 there were $68.08 \%$ of students entering elementary school came from PAUD. The quality of the student learning process seen from the AU and APS is a negative factor of the quality of education because the number of students repeating and dropping out of school shows poor quality education. Therefore, the smaller the AU and APS show the teaching-learning process is getting better so that the quality of education will increase. Ideally, it is $0 \%$, the value of AU and APS is close to zero indicating the success of free education programs in overcoming dropout rates and repeating numbers, the KKU government has provided good quality education.

The quality of student output is seen from the Navy, so the higher the AL, the better. The ideal is $100 \%$. Even though the AL value in KKU has not reached its ideal but has been at a high value with an average of $98.7 \%$ for primary and secondary education.

The RLB also influences the efficiency of education because the high RLB causes more power, time and costs used in the teaching and learning process, so education becomes inefficient. The higher the RLB value, the worse because it requires more time. Ideally for elementary school is six years and SMP / SM is three years and at KKU has achieved 
this ideal value, free education programs are very helpful in maintaining the efficiency of the education process for each education sector.

The quality of human resources is seen from GL\%,\% GS, and R-S / G because teachers are considered to determine the quality of education. \% GL is used as a measure to see teachers who teach according to the requirements in Law No. 14, 2005 concerning Teachers and Lecturers (Law No. 14/2005). (Ministry of National Education, 2005). The greater the value of $\%$ GL, the teacher is expected to teach better so that the quality of education is expected to increase. In accordance with the Act, the\% GL for SD to SM is measured by the level of teacher's diploma is a degree or Diploma 4 and higher. The ideal is $100 \%$. \% GS is a teacher who has a teaching certificate, meaning that in addition to the teacher having an S1 certificate and higher then the next step is the teacher is given certification. The higher the value, the more teachers have been certified. The ideal is $100 \%$. From table $5.14 \%$ GL is quite high, namely in the range of $79 \%-87 \%$ in elementary, middle and high school. Middle school level is the highest level in the GL\% value.

$\mathrm{R}-\mathrm{S} / \mathrm{G}$ is used as a measure to see the quantity of the teacher. If the RS / $\mathrm{G}$ number is smaller than the standard, it means teacher overstatement, whereas if it is greater than the standard, it means a shortage of teachers. National data issued by the Ministry of Education and Culture 2013 values RS / G SD 16, SMP 14, and SM 12. From table 5.14 for elementary teachers, RS / G value is smaller than this national value indicating that the teacher has an excess in terms of quantity, at the junior secondary level the value is smaller so that it is also concluded in greater quantity. However, at the SM level, it appears that this level is higher than the national score, and there is still a shortage of teachers in the middle level (SD 16, SMP 14, SM 12 National Figures 2012/2013).

For\% GS it is still quite low. The teacher certification process is absolutely the authority of the central government so that local governments do not have authority in this matter. If we look at the teacher competency test scores that have taken place from 2015, KKU education personnel have the following average scores:

\section{THE AVERAGE OF TEACHER COMPETENCY TEST SCORES IN 2015}

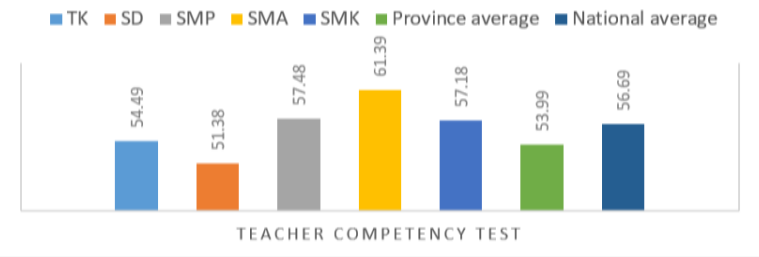

Fig. 2 The Average of Teacher Competency Test Scores in 2015

From Figure 2, it can be seen that in the 2015 UKG teachers at KKU received a high average score compared to the provincial or national averages. At the provincial level, the average UKG score of KKU teachers was ranked 6. Being in rank six shows that the quality of teachers in my school is not far behind when compared to other districts, it will remain if seen with the low average overall score, this indicates the need for more special attention from local governments in managing education programs. The teacher must be used as an object in a free education program. From the results of the interviews with the head of the school working committee meeting, it was known that the KKU government rarely carried out training programs for teachers according to the Chief Justice of the Constitutional Court.

The teaching and learning process is also determined by the availability of educational infrastructures such as good classrooms and other school facilities such as libraries, UKS rooms, and laboratories. Thus, it can be said that $\%$ of the CBD can be used as a measure to see the condition of a good classroom and also encourage students to learn better so that in the end it can improve the quality of education. The greater the value of the infrastructure, it is expected that the quality of education will increase because the learning process becomes better so that students and teachers can interact well too. The ideal is $100 \%$. In Table 5.15 infrastructure facilities whose value is good only on the \% RKB indicator at secondary education level (SM), and\% Perpusb only at elementary and SM levels. While at other levels and other indicators\% RUKSb,\% Rkomb and $\%$ Labb are all in the low percentage range.

\section{CONCLUSIONS AND SUGGESTIONS}

\section{A. Conclusions}

From the results of the research that has been carried out, it can be concluded that the free education program in the regional government of North Kayong District, West Kalimantan Province has been running effectively and in accordance with the procedures that have been set so that the criteria in the outline have been met. The details of the four components evaluated are as follows:

\section{Context Components}

Evidence of achievement is by showing related parties, especially the school as the implementing party of free education program, knowing the legal basis for the implementation of free education programs, namely the regent's regulation No. 60A of 2009 on free education and then the regulation was changed into local regulations No. 5 of Kayong Utara District 
Regulation 2014 About Free Education. Furthermore, the implementation design and process are carried out in accordance with technical instructions regarding the BOP issued annually by the KKU education and cultural services

\section{Input Components}

Participants or those who receive this free education program are students who attend school in North Kayong district with each new school year registering students always attaching family card data as proof of the North Kayong community. While the implementation of this free education program consists of parties who have competence in their fields that are shaded in the work unit of the education and cultural service in KKU where in its implementation each level of education has its own field so that planning and implementation are more organized and well organized. For sources of financing carried out with careful planning with the evaluation process from both the executive and legislative parties also request approval from the province of West Kalimantan so that the budgeting in the education and culture services is always through maximum discussion. And the allocated education function funds always exceed the mandate of the shrimp law which is higher than $20 \%$ of the APBD.

3. Process Components

From the results of the research, starting from the process of allocating time for proposals, discussions, and budgeting, all follow the schedule set by the Ministry of Home Affairs. And the budget implementation process is divided into quarterly. All components of the process are processed based on well-scheduled provisions so that the implementation of the free education program is considered to have no significant constraints.

\section{Product Components}

The increase in APK and APM values that continue to occur every year is proof of the success of this free education program, the increase in APK and APM has an impact on the rise of the human development index of the local government of KKU, the North Kalimantan Human Development Index (HDI) from 2013 to 2017 is an HDI with growth the second highest in the west west after Sambas Regency, with the growth rate of the North Kalimantan HDI of $1.35 \%$ and in 2015 the growth of the KKU HDI occupied the third level at the national level.

The increase in the number of schools both from elementary to secondary level, as well as equitable distribution of schools in each subdistrict, is evidence of the success of education in the education sector by the KKU regional government. With the exemption of tuition fees and the expansion of equitable access to education the dropout ratio in $\mathrm{KKU}$ also becomes very small.

The KKU regional government has fulfilled the minimum infrastructure facilities that schools need to carry out the learning process but for supporting facilities and infrastructure such as the UKS room, the Laboratory, Sports Fields are still very minimal in schools, so it needs further attention.

B. Suggestions

The education office as a related party in the process of formulating, implementing and evaluating policies is the party that has the most important role in the success of the free education program. From the point of view of the evaluation, in terms of providing access to the education office, it has succeeded in opening a case that is as broad as possible, will still link the quality of education prepared to be less noticed. The quality of education is influenced by 3 factors, namely the facilities and infrastructure, the student's impact and the learning process carried out by the teacher. Until now the focus of the education service was only on the preparation of facilities and infrastructure and increasing student participation. The component of improving teacher quality is still being improved. It is time to focus on improving the quality of education as students who graduate from the education level become highly competitive students.

\section{REFERENCES}

Budi Winarno. 2007. Kebijakan Publik: Teori dan Proses Edisi Revisi. Yogyakarta: Media Presindo.

Dunn, W.N. 2002. Analisa Kebijaksanaan Publik. Yogyakarta: Hanindita.

Tulung, J.M. 2014. Evaluasi Program Pendidikan dan Pelatihan Kepemimpinan Tingkat IV di Balai Diklat Keagamaan Manado, Jurnal Acta Diurna, Volume III, Nomor 3.

Nugroho, R. 2008. Public Policy. Jakarta: PT Elex Media Komputindo.

Peraturan Bupati Kayong Utara Nomor 60 A tahun 2009 tentang Penyediaan Layanan Pendidikan Gratis pada Jenjang SD/MI, SMO/MTS dan SMA/MA/SMK Sederajat di Kabupaten Kayong Utara.

Peraturan Daerah Kabupaten Kayong Utara no 5 tahun 2014 Tentang Pendidikan Gratis.

Undang-Undang Nomor 20 tahun 2003 tentang Sistem Pendidikan Nasional. 
Journal of Education, Teaching and Learning Volume 4 Number 1 March 2019. Page 14-30

p-ISSN: 2477-5924 e-ISSN: 2477-8478

Undang-Undang Nomor 32 Tahun 2004 tentang

Pemerintahan Daerah. 